\title{
FATHOM
}

\section{Being Human Within an Evolving Universe: A Study of Thomas Hardy's The Return of the Native}

Être humain dans un univers en évolution. Étude de The Return of the Native

\section{Maria Antonietta Struzziero}

\section{(2) OpenEdition}

\section{Journals}

\section{Electronic version}

URL: http://journals.openedition.org/fathom/637

DOI: $10.4000 /$ fathom.637

ISSN: 2270-6798

\section{Publisher}

Association française sur les études sur Thomas Hardy

\section{Electronic reference}

Maria Antonietta Struzziero, « Being Human Within an Evolving Universe: A Study of Thomas Hardy's The Return of the Native », FATHOM [Online], 4 | 2016, Online since 15 October 2016, connection on 21 April 2019. URL : http://journals.openedition.org/fathom/637 ; DOI : 10.4000/fathom.637 


\title{
Being Human Within an Evolving Universe: A Study of Thomas Hardy's The Return of the Native
}

Être humain dans un univers en évolution. Étude de The Return of the Native

\author{
Maria Antonietta Struzziero
}

\section{Introduction}

1 The discourses of degeneration / renovation appear to be present in Thomas Hardy's The Return of the Native: on the surface, the text traces the plot of decline and seems to endorse the discourse of degeneration, engaging with issues and motifs typical of this ideology. Yet, by employing Pierre Macherey's technique of "reading against the grain" and penetrating the text's ambiguities and silences, we can disclose a subtext that "reveals the inscription of an otherness in the work" (Macherey 79), hidden by the language of ideology which subtly tries to impose its 'truth'.

2 As the novel problematizes the construction of gendered subjects, it is crucial to see how Hardy textualizes sexuality within the ideological framework of his time. A close reading of his fiction aiming at revealing its internal operative principles will be undertaken, a methodology informed by Louis Althusser's view of ideology as a system by which individuals are interpellated and "called upon to recognise themselves as certain types of gendered subjects" along the axis of the feminine and the masculine fixed by the dominant ideological discourses and to take up "a position within a hierarchised system of gendered differentiation" (Mills 43). Importantly, however, Michel Foucault argues that though discourse has a repressive function, it can also offer "a point of resistance, and [...] an opposing strategy" (Foucault 101) to expose the artificial nature of the gender codes which are at the heart of the patriarchal order. This strategy will be applied to Hardy's text where oppositions often emerge as silences and ambiguities, textual markers of the writer's resistance to a conservative conceptual order, when language refuses to settle into a unitary meaning. The gendered silences and tensions of Hardy's novel reveal 
different voices intersecting and opening up spaces for the construction of male and female subjects articulated against traditionally accepted models.

This paper maintains that the novel's subtext does not validate the view of his characters as 'degenerate' creatures. Rather, it reflects Hardy's philosophical view of an evolving universe and of individuals caught up in inevitable, neutral processes of change, as part of what Henri Bergson called creative evolution, the general movement of life which is continually developing and generating new forms, a process in which even the death of the single individual is accepted for the greater progress of life in general. Hardy's creatures can be read as expressions of a subversive free consciousness fighting to impregnate matter with their creative powers and to transform the 'degenerate' nature of social institutions and conventions, and the limitations of gender divisions, "particular manifestations of life [that] accept [...] mobility reluctantly, and constantly lag behind" (Bergson 141).

4 It is also possible to decode the tendency of some of Hardy's characters to illustrate a shifting gender profile, moving across permutable gender boundaries, in terms of an 'intertextuality'. They can be understood as Julia Kristeva's subjects in process described in her Desire in Language. Their identities can be interpreted as being in a state of 'generative instability', in a constant dialogic process between the two heterogeneous modalities represented by the unconscious drives and the social, the semiotic and the symbolic.

In its combination of masculine and feminine attributes, Kristeva's semiotic is disruptive because in this disposition the subject is offered the possibility to explore different sources of signification and she/he tends towards identification rather than separation from what is other. This subverts the rigid system of binary gender oppositions imposed by the symbolic order and originates a new system where the plenitude and diversity of individual identities are viewed as potentials for a continuous generative process, and deviation, not adherence to the norm, should be considered a creative principle.

6 In the following sections it will be argued that only apparently in Hardy's text the narrator seeks to fix the characters' identity within stereotypical gender roles. Actually, when the seemingly firm borders of the symbolic order are loosened, in the novel's subtext we discover that, far from exploring the degenerative model, Hardy probes the breakdown and transformation of the old, limited, symbolic order into a semiotic paradigm of the creative energies at work in the cosmos.

\section{Natives and intruders on Egdon Heath}

7 Analysis of the structure of the novel discloses the intersection of two opposite narrative trajectories, a degeneration and a regeneration plot. In each plot there appears to be a careful patterning of character types built on a traditional binary opposition within and between genders, with the final validation of regenerative values and the punishment of transgressiveness. Within the surface degeneration plot Eustacia, Clym and Wildeve display different symptoms of degeneration whose roots are variously located.

8 Eustacia, with her restless, sensual nature and her "instincts towards social nonconformity" (Hardy 1999, 72), manifests evident symptoms of moral degeneration, a fallen woman who, according to Perry Meisel, functions as a catalyst that, through Clym, infects the community by activating the latent germ of its destruction and is consequently branded as "a witch" and "a hussy" (Hardy 1999, 52; 192). She brings about 
Clym's social isolation and becomes the paradigmatic exemplification of a woman who lives "on the borderlines of the symbolic order [...] dangerously part of chaos itself" (Showalter 8). Her movements are not inhibited by suffocating family ties so she represents a threat to a male-dominated world where domesticity and docility in woman are expected and affirmed.

9 A further symptom of degeneration is to be found in Eustacia's tendency to move across gender boundaries, as she does during the mumming play when she embraces a dynamic masculine role, rejecting her femaleness. Her degenerate nature can also be located in her disturbing sexuality and in the open expression of her desire "to be loved to madness" (Hardy 1999, 71), as she does in the gipsying episode when she dances with Wildeve.

The events leading to her death appear to inscribe the normative pattern of a plot punishing transgressive women, a conclusion proleptically announced by the mumming episode, when she is killed in battle, gradually "sinking to the earth". As a woman she is silenced first by Clym, who imprisons her in "the mire of marriage" (Hardy 1999, 135, $322)$, then definitely by death. In this scheme, her end is the act of a sinister providence which destroys the source of chaos and re-establishes order and morality in the community, cleansing it from those forces that fail to conform and threaten to disrupt social order.

11 In Clym degeneration manifests itself both as progressive social marginalization and as physical decline. His first step towards social isolation is represented by his marriage to Eustacia - which begins the curve of his decline - when he has to move to the margin of Egdon Heath. Gradually he also has to readjust his initial ambitions and give up his aspiration to be a teacher because of his failing eyesight, the next stage in his degenerative process and the visible manifestation of the "disease of the flesh" (Hardy $1999,137)$ associated with thought. The final step in his declining process is his decision to degrade himself to being a lowly furze-cutter who becomes one with the land he toils, transformed beyond recognition also to the animal world of the flies that "buzzed about him without knowing that he was a man" (247). The degradation of Clym and his disintegration in Eustacia's eyes are rendered in unequivocal terms by Hardy. Clym is "of no more account than an insect [...] a mere parasite" (270). The image of the parasite was typical of degeneration discourse and mentioned by Edwin Ray Lankester in Degeneration: A Chapter in Darwinism as an instance of regression. In the last book, Clym seems to be one of those fin de siècle figures Elaine Showalter identifies as the "borderliner [...] whose mind [...] felt the lack of 'directing' or 'controlling power"' (Showalter 10-11).

Wildeve appears to embody the stereotype of the manly man who contrasts with the intellectual, tormented Clym. However, when he is introduced, he has already started tracing a descending parabola: from being an engineer in Budmouth he is wasting his talents as an innkeeper on Egdon Heath. His return to Eustacia after their respective marriages is as dangerous as Clym's return to Egdon, and definitely assigns him the unpleasant "role of the feckless catalyst of catastrophe" (Deen 127).

In the regeneration plot, Thomasin is the "practical woman", reassuringly "pleasing and innocent" (Hardy 1999, 156; 65), always concerned about traditions and other people's moral judgement of her. She is the sign of the well-regulated heroine, a type of woman who achieves self-fulfilment in the domestic sphere. Her moderate, sober affections, supported by "the power of her own hope" (159), and her adaptability balance and triumph over Eustacia's excess of passions and restlessness. 

unnaturally confused with his activity, becomes respectably visible and even restores the previous order to the Egdon community. Venn's inverse parabola is punctuated also by his successful celebration of the virtues of marriage with Thomasin in the final domestic scene of bourgeois domestic life, set against Clym's failed marriage which has been at the heart of the novel. He finally achieves what he desires: the rebels who have been the source of the community's disorder are definitely removed and the cautious survivors are rewarded for their adaptability to social rules and conventions. gender and class, is deceptively simple and misleading, as it does not account for the many silences and contradictions in the text to be traced at deeper levels of the novel's texture. In fact, a close reading shows that the degenerate protagonists are not the supposed threatening agents of disorder. Rather, viewed within $19^{\text {th }}$-century ideas about evolutionary processes, each of them is a creative thrust that, clashing against hostile institutions and defying those classifications that underpin the hypocritical moral and social codes of the community of Egdon Heath, sets off necessary transformations.

The alternative reading of The Return of the Native I intend to suggest must necessarily start from a decodification of the 'text' of Egdon Heath, a metaphorical landscape that compresses the whole geological history of man in its different layers, a text impregnated with the evidence of the evolution of the landscape and of the species that have colonized it. The sense of historical stratification forces human beings into an awareness both of their dwarfish insignificant position against the backdrop of evolutionary time and of the absolute indifference of the universe to their plight. double world: on the one hand, the past in which all individual contributions have been fused into a whole rock and lost in its layers; on the other, the present which is potentially open to both development and death. The idea of development is signalled by the positive image of the "great and particular glory" of the heath that "appeared slowly to awake" (Hardy 1999, 9; 10), or the cluster of signifiers implying transformation: "renewed" and "changed" are massively repeated on the last page of the chapter. The idea of death is evoked by the images of "darkness", "night", and "gloom" that punctuate this section, as well as by the "face [of the heath] suggesting tragical possibilities" $(9,12$, 11). So, on closer inspection, the apparent stability of the heath discloses an ongoing process as it is "unstable", "flickering" (21), evanescent in the light of the bonfires.

y decodes Darwin's evolutionary theory in terms of creative evolution, a view that integrates man with man and with all life in some creative thrust. His focus is on the "unforeseen" (Hardy 1999, 373) side of the evolutionary process; this means that in his fiction he investigates the ways in which man's modern awareness of the natural laws and his conscious will can grasp such laws and, by doing so, originate variations on the whole material reality, both in terms of new forms of life and of institutions based on different ethical codes. Thus he represents biological and social processes at work, still unknown as to whether they are positive or negative.

19 The first chapter is a visual and emotional correlative of the mechanisms of creative evolution as described by Henry Bergson in Creative Evolution: "Life [...] is a tendency to act on inert matter. The direction of this action is not predetermined; hence the unforeseeable variety of forms which life, in evolving, sows along its path" (Bergson 107). 
The opening page sets the heath at a crucial moment, a "transitional point" when this wild landscape - which "seemed to await [...] the final overthrow" (Hardy 1999, 9-10) - is going to witness one more change. The process of clash and consequent transformation will be triggered off by Eustacia, the Promethean "Queen of Night" (68), who awakens Egdon Heath from its sleep, colliding with it. The theory of creative evolution also opens up a different insight into the novel, disclosing that the conventional critical decodification of Eustacia as a degenerate agent of disorder is not actually validated by the text. Just before she is introduced, the valley is presented as being in a state of "incredible slowness", in "a condition [...] nearly resembling the torpor of death" and its inhabitants are "grotesque [...] preternatural" presences $(16,21)$. Eustacia first appears at this moment of impasse, not as a border figure but as "the pole and axis of this heathery world", as its "delicate and necessary finish", "an organic part" (17) of the barrow.

20 As a result, episodes and motifs that appear to plot the degenerative theme can be decoded differently. This happens, for instance, with the mumming play, an episode that is illustrative not of degeneracy but of a different perception of gender formation. By traversing gender boundaries with her cross dressing, she exposes these very boundaries for what they are, thus rejecting the ideological meanings loaded with prohibitions and taboos attached to woman and affirming the creative semiotic paradigm of the inner self. Evolutionary theory had shown that common forms were still in a condition of change, that the body - which "resolves itself into a group of qualities - [...] is still unstable in that it changes quality without ceasing" (Bergson 328). So Eustacia's permeability to a different identity points forward to a shift in the feminine sign and to a view of gender as an ongoing process, and exemplifies a typical post-Darwinian tendency "to deny permanent identities or sharply defined categories - even of good and evil” (Levine 17).

21 Also the gipsying episode does not signal Eustacia's degeneracy: even though the transgressive nature of the dance is clearly signalled by its being associated with "an irresistible attack upon [...] social order" (Hardy 1999, 257) and the community's traditional power relations, it can be viewed as the gesture of rebellion of a woman who refuses entrapment in a world where masks are taken as essences, the 'mask' being merely an imposed role and identity, socially contrived and ideologically constructed. Besides, it answers a basic natural drive, what Hardy calls the "determination to enjoy" (Hardy 2007, 219) which runs through all nature.

Actually Eustacia is the "irrepressible New" (Hardy 1999, 12), a new cultural organism that contributes to create diversity: she is not a passive vessel of evolutionary process but proactive, a dynamic spring of change. Her disruptive nature is merely a neutral element: she is a stirring up principle, a jolt necessary to move a stagnant reality and generate a more modern consciousness, daringly moving between and diluting traditional ethical binaries. She proves that "one of the qualities of man is his ability to create, and to change what he creates" including "man's social laws and institutions" (Southerington 121). Eustacia's vital energy acts as Bergson's "initial impulsion" which opposes the weight of matter in the form of worn-out institutions and stereotypical gender divisions, and "insert[s] some indetermination" (Bergson 268, 139) on it generating necessary variations. The heath-dwellers and Mrs Yeobright resist her creative movement afraid of the girl's 'deviant' nature, anxious to discipline and neutralise her as a source of disorder. Yet, for Bergson, disorder is simply one of the two forms order can take in reality and it only corresponds to man's “disappointment of a certain expectation" (298). It all depends 
on our limited view of the world which we are unable to perceive as becoming, and on what our idea of order is.

So, viewed within $19^{\text {th }}$-century ideas about evolutionary processes, Eustacia is not the supposed spring of chaos but a force that fosters inevitable transformations, because the evolution of life is not mere adaptation, but a creation constantly renewed and renewing. By exploring alternative behavioural paths, she embodies a form of creative divergence, a divergence that only implies difference, not degeneration. She is 'other' to the patriarchal system of the heath dwellers who, in their superstitiousness and repressive conventional morality, cannot conceive that the creativity of diversity is the true medium of development. Her death is ambiguously left in the dark, a choice that problematizes the text.

24 As with Eustacia, also with Clym Hardy explores a new type of male identity: in his somewhat asexual ethereality, he is in the process of constructing a new gendered identity for himself, rejecting the ideologically entrenched myths of virility and power commonly taken to signify 'man'. He epitomizes the psychic evolution of a sensitive modern intellectual, agonizingly alienated from life and painfully conscious of the tragic quandary in which intelligent human beings are. The intellectual as well as biological evolution of man, superior to any other form of life, is bound to make him unhappy because he is aware of the "defects of the natural laws" (Hardy 1999, 167) that scientists and biologists were discovering, which assigned no special place to the human. Yet, this awareness does not provoke passive resignation in him. He has survival tactics, will and endurance, qualities which he draws upon when occasions demand, as happens when he is almost blind, must give up his studies and takes to furze-cutting, proving that, even in its adaptations to changed conditions, there is inventiveness in the evolution of life.

At one point there is an anthropomorphic image of Clym as a "brown spot" whose "familiars were creeping and winged things" (Hardy 1999, 247), a scene which elides all distinctions between man and other creatures in nature. But his perception of a sense of wholeness is short-lived: at the end of the novel, he re-emerges as a solitary, isolated figure on top of Blackbarrow, which proves that it is impossible to choose to revert to a prior state. However, this final image can also be viewed as the celebration of his recuperative energies, of personal will emerging after defeat, suffering and death, responding actively to the environment and ready to start anew, a reaction that is crucial to the movement of life. Unlike Eustacia, he accepts life's "limited opportunities" (Hardy 1974, 285), rather than striving after ambition and passion, a resilience that guarantees his survival; with the tragic knowledge he has acquired, he embraces an altruistic, if strongly utopian doctrine of amelioration.

Also the neat binary opposition between Eustacia and Thomasin - the 'seductress' vs. the 'womanly woman' - actually ignores the fundamental uncertainty betrayed by the narrator's language when portraying Eustacia, which calls for the reader's responsive understanding. An alternative critical interpretation is to see Thomasin as the woman who never questions the moral values of her society and the 'normal' female behaviour expected of her. Whereas Eustacia is continuously flouting conventions, eager to push at boundaries, the submissive, compliant Thomasin internalizes patriarchal dictates unquestioningly and affirms them.

The final celebration of the marriage between Thomasin and Venn could be decoded as a modest affirmation of norms set against the degenerative ones connected with Wildeve and Eustacia, a bourgeois "synthesis of property and propriety" (Fisher 85). This 
interpretation, though, fails to account for Hardy's management of sympathetic reader responses in the text and for the disturbing ambivalences in Venn's character. In reading against the grain, he is the censorious puritanical conscience of his age whose selfappointed role is that of the moral censor complicit in Egdon's regulatory structure, obliquely disapproved by Hardy. Evidence for the novelist's attitude is discovered when reading retrospectively. Even the title given to the second chapter where Venn is introduced, "Humanity appears upon the scene, hand in hand with Trouble" (Hardy 1999, 13), is particularly apposite as, in fact, he does bring trouble with him. He is often creeping and spying, an activity "to which he had cynically devoted himself" (82), perpetually meddling. His behaviour reveals a malevolent underside which Hardy exposes, portraying him as a "blood-coloured figure" stamped with "the mark of Cain" (79). He is a manipulator: from his position as a reddleman he sets things going with his covert surveillance and machinations, but the results of his interventions are often negative and he achieves the opposite effects.

In introducing Venn, Hardy describes him as "a curious, interesting, and nearly perished link between obsolete forms of life and those which generally prevail". In the rural world of the heath, he fills the place that in the past century "the dodo occupied in the world of animals" (Hardy 1999, 14, 13). He represents a 'vestigial' form on its way out, coming somewhere between the extinct dodo, what is current and what will come after, a functionary within Hardy's vision of a changing universe. He is not quite extinct yet, not a distinct species in itself but a medium for mutation furthering the evolution of other stages.

\section{Being human in an evolving universe}

In the previous section the analysis of the subtext of The Return of the Native has revealed the conflicting interaction between the personal world of individuals and the social world of institutions and moral codes that the characters often perceive as hostile because set in opposition to their needs and desires. In this part I will link what has emerged from my analysis of the novel's subtext to Hardy's wider cosmic perspective, arguing the following points: first, the human world that Hardy discloses is not degenerate nor can it be regenerate. The creatures that people his narratives are undergoing the same processes of transformation as the rest of the cosmos which endlessly produces new, unpredictable forms of life. Second, these changes involve every single living organism and imply generation as well as decay and death. Such processes, though perceived as cruel and unjust when viewed from a human perspective, are necessary to further life in the universe and neutral because all creatures obey the same universal laws. Hardy's two worlds, the human and the cosmic, will be explored and linked to the Bergsonian theory of creative evolution.

30 In the novel Hardy presents the universe as a living, evolving organism that has developed by slow secular processes. All forms of life in it, connected in infinitely complex relations, are regulated by the same cycle of evolution, adaptation and extinction. To establish his view of an organic universe, Hardy compares or associates different forms of life, caught up in transformation.

31 After the break with his mother, Clym sees "young beeches [...] undergoing amputations, bruises, [...] lacerations" that leave bleeding "scars" (Hardy 1999, 207). A scene similar to this one, though with more complex psychological implications, is the one Mrs Yeobright 
views on her 'journey' across the heath to Clym's house. She observes a succession of images of nature in the process of change, withering away, undergoing decay or precocious death in a very short span of time. Plants that in the morning are tender, are "flagged by ten o'clock", "stiff cabbages" are "limp by noon" and trees are "splintered [and] distorted" $(269,271)$. It is the view of a reality in movement and of forms continually changing. This incessant process of change, which privileges neither man nor the present, is set against the vast impassivity of the universe. Each element of this composite natural world is an index of the struggle for existence in difficult, oppressive conditions. In these scenes, Hardy "speed[s] up the film of evolutionary struggle" (Greenslade 328) to make it accessible to human perception. Besides, he shows that the varieties of vegetable, animal and human life inhabiting his world are merely undergoing natural, neutral processes of generation, growth and death. Their transformation cannot be decoded as a degenerative tendency but simply as the inexorable change inherent in the life cycle of all organisms in the cosmos.

At one point Mrs Yeobright comes to a "nearly-dried pool". She sits down to rest and her look is caught by the puddle teeming with a profusion and variety of life in movement. At first her attention is attracted by the "mad carousal" of flying "ephemerons". Then, among the "vaporous mud", she sees a microcosmic Darwinian tangled bank of "innumerable obscene creatures", a plenitude of forms whose movements communicate a fleeting impression of "happiness" to the old woman who is excluded from their sense of "enjoyment" (Hardy 1999, 270). This creates a moving tension because she discovers that plenitude also implies imperfection, loss, waste. In the pre-Darwinian order there was a hierarchy with man at the pinnacle, endowed with authority and complacency that all was created for a human reason. There is no such privileged position for the human in the Darwinian natural world. Enjoyment is allotted to the ephemerons whose life embraces only a single time-scale; a human being, Mrs Yeobright, can only empathize with their condition for a moment. Unlike these creatures, she is conscious of different time-scales, both of the incommensurate time of the universe spanning over aeons of geological history and of the irrelevant, transient life of man.

From his all-encompassing perspective, which is like a camera-eye, the narrator frequently has a double vision in the novel. He has both the overview of the 'god' person of what is infinitely great and the view of what is infinitely little, with a close examination of all minute details. This happens in the episode preceding Mrs Yeobright's death when, on her way back from Clym's house, prostrated, she stops to have some rest, vaguely perceiving that she is approaching death, the end of her journey. Her eyes move from the near to the distant, shifting in space and changing scales, disclosing a whole "unseen insect world". The image she observes is gradually amplified: she notices "a colony of ants", microscopic creatures engaged in the same "never-ending" normal routine of toiling for life as "their ancestors" did in "old times". Then, looking upward, her vision embraces "a heron" flying "towards the sun" (Hardy 1999, 282). Her observation of different conditions and living creatures is accompanied by a simultaneous identification with them. On the one hand, she is conscious of being crushed, "pinioned" to the toiling of everyday life like the ants; on the other, her mind's intense aspiration is to escape "all contact with the earthly ball" and be finally free. Mrs Yeobright's journey across the heath encapsulates the consciousness of a whole existence as, at the end of it, she has internalized the idea that life goes on despite "the prostration of the larger animal life" (282). All the animals she has observed on the vast expanse of the heath, 
despite their different state, have somehow "been useful traveling [sic] companions" on her journey and her "consciousness has unloaded whatever encumbrances it was dragging along". This has enabled her consciousness "to rise [...] to heights from which it sees an unlimited horizon open again before it" (Bergson 290-291). Her epiphany comes when she exchanges a look with the adder that had bitten her and is melted to save her, both pointless deaths from a human perspective. The terrible, wonderful truth is that life goes on driven by an irreducible life force and, with it, the struggle for existence of other creatures like her in an endless process. Hardy opens up a field of vision which includes both the fleeting moment of a plant's life and geological time. This underscores how systems which extend beyond the life span of the individual cannot serve his needs but "the longer needs of the race and are part of a procreative energy designed to combat extinction, not the death of any individual" (Beer 224).

In his cosmic vision, Hardy embraces the vast interstellar spaces of the universe at one extreme and the tiniest creatures at the other, pitting the pathetic vulnerability of human beings against the inscrutable mystery of the universe. Shifting from macroscopic to microscopic forms of life, from the human to the animal, from the present to the very distant past, he relativizes everything, including human suffering and death, when observed from a universal perspective. Yet, in his sympathetic loving-kindness, when Hardy narrows down his view to the human level of living, suffering beings, he shows them in their heroic greatness. Even when defeated, he celebrates their endurance and moral strength.

The evolutionary model in The Return of the Native begins with the description of the empty heath and is brought to a further stage with the appearance of "humanity upon the scene" in the second chapter. At first it is a "single atom of life" (Hardy 1999, 13), then the narrator zooms in on the figure of Eustacia on the barrow. "The entire motionless structure" is magnified by the contrast with the tiny human figure rising on it which, instead, "turn[s] around" and, "as if alarmed" (17-18), descends. On the one hand, her movement signals her autonomous existence from what appeared to be a single, homogeneous structure and the assertion of human will. On the other, it shows Eustacia's mistaken decodification of the indifferent face of the heath for a malignant force which, in fact, provokes her alarm. The scene in which she appears is a microcosm symbolizing the quintessential antinomy at the heart of Hardy's artistic production, unequivocally voiced in the Preface to Two on a Tower. His constant subject is the "emotional history of [...] infinitesimal lives against the stupendous background of the stellar universe" (Hardy 1975, v). In The Return of the Native it is Eustacia against Egdon Heath, in The Dynasts the antinomy is embodied by "shapes that bleed, mere mannikins or no" (I, l. 88; Hardy 1995, 17) against the Immanent Will.

The scene on the barrow encapsulates Hardy's conception of man's self-conscious conflicting relationship with the indifference of the universe. Besides, the heath's "ancient permanence" is a reminder of human life's impermanence and its imperturbable countenance is pitted against the conditions of existence. To "human vanity", the heath will only oppose "a certain vein of satire" (Hardy 1999, 12). Eustacia's displacement from the barrow signals that human beings, like the smallest worm or mollusc, are inescapably subject to the processes of natural selection. Her displacement also implies that it is no longer possible to interpret the world anthropocentrically and this exposes man's marginality. 

with "a spontaneous, Promethean rebelliousness" (Hardy 1999, 21). Her creative nature comes into collision with human beings who uncritically simply prefer to follow the " Custom of the Country" (18), obeying the set of signifying systems established by the symbolic order. The novel actually plots "the unrolling of this conflict" which is "the evolution of the organized world". Eustacia's rebelliousness follows the free impulse of her creative desire and, in her movement, she inevitably meets with "materiality [which] is the inverse movement" (Bergson 227, 272). Her life tends to penetrate the "inviolate place" (Hardy 1999, 12) and "to insert some indetermination" (Bergson 139) into it to break through its resistance. In order to see her desires fulfilled, she uses some energies such as persistence and ingenuity and, faced with the necessity to act, she chooses the course of action that can serve her best in that situation. So to meet Clym she transforms herself into a mummer and to get him she furthers Wildeve's marriage to Thomasin so as to overcome the obstacles placed in her path. Yet, as she lacks patience, in the end she cannot see that, to break the resistance of matter, she should act in the same way as life that insinuated itself into matter "in order to draw it little by little [...] to another track" (Bergson 110). sort of relationship with Mrs Yeobright and, at a crucial moment, she keeps the door closed. Besides, having realized what has really happened, she does not take any action, thinking that, "No man can change the common lot to rare" ("To an Unborn Pauper Child", Hardy 2001, 127-128). Clym behaves similarly as he keeps delaying both the visit to his mother and the reconciliation with his wife. Loneliness, lack of co-operation and inability to communicate characterize them and contribute to bring about the events that will provoke the death of both women.

Eustacia's failure proves that the force "evolving throughout the organized world is [...] limited" and man's efforts can be "paralyzed by contrary forces, sometimes diverted" (Bergson 140-141). In the end, she clashes with the resistance she meets from a hostile environment and its decaying institutions. Despite her final silencing, in her struggle for independent self-assertion Eustacia evolves an essentially free consciousness and, in her choice of responding actively and creatively to her environment, she furthers change. The community of Egdon Heath is still anchored to worn out, false beliefs and oppressive morality; preoccupied with surveillance, punishment of transgression, and retribution of 'proper' behaviour, it does not see that the whole world around is evolving and that it will be left behind.

40 Eustacia is not bowed by a hostile Immanent Will. What defeats her is her highly sensitive nature and her firm conviction that her "desires must have some creative value, some power of modifying the worldly process" and her wish to "make it conform to the world of [her] imaginative pride" (Abercrombie 65, 85). Her oppositional beliefs make her less flexible and, consequently, susceptible to be crushed by a hostile environment. Yet, she leaves a legacy of new, revolutionary ideas behind that permeate both her 'text' and life coming after her.

41 Unlike her, Venn survives because he refuses to accept defeat and pursues his objectives with endurance and doggedness. He looks ahead, watches his enemies, is always ready to adapt himself and his actions to changed circumstances and wins, using every possible trick and strategy. He is the quintessential representation that in nature there is no 
philosophic resignation. He acts as a catalyst between outmoded forms of life and new types, a missing link as it were, favouring the transmutation of the 'cells'.

Hardy, however, opposes a reading of change in terms of preordained fate, and his characters are mistaken when they view their life as the central concern of a malignant "Supreme Power" (Hardy 1999, 253) who enjoys seeing them groan on the earth. It is a form of proud self-centredness that makes Clym occasionally believe that a First Cause thrusts irons into men's soul or Eustacia blame "Heaven" for "putting [her] into this imperfect, ill-conceived world" (346). The Will is neither benevolent nor malevolent, only indifferent; what happens to them is simply part of the nature of the struggle for existence in an evolving universe in which all living creatures are undergoing processes of transformation, "just neutral-tinted haps and such" ("He Never Expected Much", Hardy 2001, 886), without moral significance. Men's predicament is tragically distinctive because, though "figments" they can feel: among all living things they are the only ones to be aware of their suffering, a consciousness that also contrasts with the Unconscious Will immanent in the universe.

Still, Hardy does see a glimmer of hope: in a moment of equilibrium of the Universal Will, the "little cell called [...] life" (Hardy 1985, 13), has its part, infinitesimal though it might seem to be, and is allowed to be free. So, within the framework of certain overriding laws, the individual 'cell' has its place, its power and a limited influence in its own sphere as the final paragraphs of The Return of the Native suggest.

\section{Conclusion}

The analysis of The Return of the Native has opened up a double level of decodification of the novel. The pattern of ideas emerging on the level of literal narrative certainly suggests the view of a writer who endorses the social, biological and cultural degenerationist frames of reference. In fact, the surface of the text is imbued with degenerative discourses in which the protagonists and their stories are variously embedded, and different types of degenerative processes have been identified, mostly connected with physical deterioration in Clym and with the 'degenerate' sexuality of Eustacia.

Yet, by reading against the grain and adopting a more flexible and intuitive critical approach, we have seen that the novel reveals a subtext which suggests a much more complex understanding. At this deeper narrative level, it has been observed that Hardy, "slipping in and out of contemporary discourse" actually offers his creatures "the possibility of a subversive, if crude, resistance to the terms of incorporation and exile held out by the dominant social order" (Greenslade 64). In reality, the characters in his novel are cast in the roles of degenerate by a patriarchal power alarmed by the contaminating presence of the new that threatened its moral, social and sexual codes. It has also been noticed that, alongside the ideological discourses of degeneration / generation, the other major narrative presence in Hardy's texts is that of Darwin. Evolutionary theory, with its double possibility of creation and extinction, offered a narrative pattern to decode and plot experience. Besides, it fascinated Hardy with its view of an evolving universe and, against its background, creatures caught up in its inescapable motion and transformations. This aspect of the theory affected Hardy profoundly and led him to conclude that the Newtonian laws and social paradigms were flawed and were responsible for man's unhappiness. Sweeping away the idea of an 
immutable creation, human beings became subjects in process, pluralized identities never fixed and finished, fluid forms uncontainable within the binary gendered polarities imposed by the symbolic order. A view of identity as performative.

The subtext of The Return of the Native discloses just this process: the human predicament explored at a crucial moment and on-going in its long history, viewed within a double frame, the human and the cosmic. On the one hand, there are old forms of life that survive thanks to their ability to adjust to specific circumstances of their environment in their own interest. Such are Venn, Thomasin, Clym; on the other hand, there is the passionate struggle of sensitive, rebellious human beings who, with their highly refined consciousness, collide with an indifferent universe and with the patriarchal system of social and institutional structures that, through taboos and prohibitions, denies any free subject position to those who assault its authority. The vital energy of these rebel characters tends to generate changes in a reality still tenaciously clinging to conventional moral codes, such as those concerning gender relations.

Hardy sees the necessity of human adaptation but he also admires "the strength of those who attempt [...] to break through the limitations of necessity" (Southerington 232), as suggested by his subtle balance of sympathies for this type of character. What really interests him is the creative power inherent in the life force that implies more than mere adaptation. As in nature, the living beings inhabiting his fictional world are all part of the same organism, related in several ways and mutually dependent. Their individual diversity is necessary for more than one reason: first, they contribute to ensure the survival of the environment that ultimately depends on the coexistence of a multiplicity and variety of life forms. Secondly, the 'deviant' creatures contribute to channel the immense river of life towards unexpected, unforeseeable directions. In doing so, they sow ideas that set off further essential processes of transformation and generation and maybe accelerate them.

Hardy's profound humanity and concern for the suffering of all living things, makes him opt for narrative plots in which he acknowledges man's developed consciousness and so gives dignity and worth to all his small, insignificant "mannikins". He accomplishes this first, adopting "the single life span as his scale". Ending his novels with the death of the protagonist, he "opposes evolutionary meliorism or pessimism by making the single generation carry the freight of signification" (Beer 223). Second, he sets the life of the single individual against the backdrop of evolutionary time. This is crucial to capture the essence of his narrative: any single individual and the energies that urge her/him on are absolutely precious and have a vital function, which is to contribute to the continuance of the species.

49 In conclusion, though The Return of the Native is impregnated with degenerative motifs and language, Hardy does not present a world of degenerates who undermine the delicate balance of the social order thus jeopardizing the survival of the others. Neither does he welcome degeneration as the catalyst for regeneration as Friedrich Nietzsche did. Both ideas would entail a model of winding down and up to some ideal type, a perfection that is excluded in Nature, in which the key word is process. The degenerative elements, understood in the context of his double perspective, the human and the cosmic, are to be perceived within a wider vision where dissolution and transgression imply inevitable forces at work which are neither pessimistic nor progressive but neutral. the narrative of their lives giving a meaningful artistic shape to what was originally the 
flux of "a series of seemings" (Hardy 1985, xxxv-xxxvi). Once his pattern is completed, his creatures, free from the constraints of an imprisoning present, at last can become again only indistinct particles in a universe where generation and transformation are acknowledged as the prime cosmic urges.

\section{BIBLIOGRAPHY}

Abercrombie, Lascelles, “Thomas Hardy”, Thomas Hardy: Critical Assessments, vol. II, ed. Graham Clarke, Mountfield: Helm Information, 1993, 60-128.

Beer, Gillian, Darwin's Plots: Evolutionary Narrative in Darwin, George Eliot and Nineteenth-Century Fiction, $2^{\text {nd }}$ edn, Cambridge: CUP, 2000.

Bergson, Henri, Creative Evolution, New York: Random House, 1944.

Deen, Leonard W., "Heroism and Pathos in The Return of the Native", Hardy: The Tragic Novels, ed. R. P. Draper, London: Macmillan, 1975, 119-132.

Fisher, Joe, The Hidden Hardy, London: Macmillan, 1992.

Foucault, Michel, The History of Sexuality: An Introduction, New York: Vintage, 1990.

Greenslade, William, Degeneration, Culture and the Novel 1880-1940, Cambridge: CUP, 1994.

Hardy, Thomas, The Return of the Native (1878), ed. Tony Slade, London: Penguin Classics, 1999.

Hardy, Thomas, Two on a Tower (1882), ed. F. B. Pinion, London: Macmillan, 1975.

Hardy, Thomas, The Mayor of Casterbridge (1886), ed. F. B. Pinion, London: Macmillan, 1974.

Hardy, Thomas, Jude the Obscure (1895), ed. Patricia Ingham, Oxford: OUP, 1985.

Hardy, Thomas, The Complete Poetical Works, Volume IV: The Dynasts, Part First and Second, ed. Samuel Hynes, Oxford: Clarendon, 1995.

Hardy, Thomas, The Complete Poems, ed. James Gibson, Basingstoke: Palgrave, 2001.

Hardy, Thomas and Florence Emily Hardy, The Life of Thomas Hardy, 1840-1928, intr. Michael Irwin, Ware: Wordsworth Editions, 2007.

Kristeva, Julia, Desire in Language, ed. Leon Roudiez, New York: Columbia UP, 1980.

Lankester, Edwin Ray, Degeneration: A Chapter in Darwinism, London: Macmillan, 1880.

Levine, George, Darwin and the Novelists: Patterns of Science in Victorian Fiction, Cambridge, Massachusetts: Harvard UP, 1988.

Macherey, Pierre, A Theory of Literary Production, London: Routledge, 1978.

Meisel, Perry, Thomas Hardy: The Return of the Repressed, New Haven: Yale UP, 1972.

Mills, Sara, Discourse, London: Routledge, 1997.

Southerington, F. R., Hardy's Vision of Man, London: Chatto \& Windus, 1971.

Showalter, Elaine, Sexual Anarchy: Gender and Culture at the Fin de Siècle, London: Virago, 1992. 
Wain, John and Eirian (eds.), The New Wessex Selection of Thomas Hardy's Poetry, London: Macmillan, 1978.

\section{ABSTRACTS}

This paper argues that the surface narrative of Thomas Hardy's The Return of the Native appears to endorse late $19^{\text {th }}$-century degeneration theories and discourse, illustrating a gender crisis. However, by decoding and laying bare the textual ambiguities, a subtext is disclosed that inscribes an alternative reading in which tradition and convention are subverted. Therefore the novel opens up a more complex interpretation of what it means to be human in an evolving universe. The narrative of The Return of the Native clearly shows that Hardy is fully cognizant of the controversial fin de siècle degeneration discourse. Yet, viewed in the context of $19^{\text {th }}$-century ideas about creative evolution and Hardy's response to these, we realize that he exposes such discourses as deeply suspect ideologies. Analysis of the structure of the novel brings to light the intersection of two opposite narrative trajectories, a degeneration and a regeneration plot. In each plot there appears to be a careful patterning of character types built along stereotypical gender and ethical binary divisions, with the final validation of regenerative values and the punishment of transgressiveness. Actually, a close reading shows that Hardy attacks the 'degeneracy' not of the human species but of the social institutions and conventions which his protagonists must struggle against. He flouts the limitations of gender divisions and gives life to characters who become signifiers of a new and powerfully disturbing view of masculinity and femininity within contexts wider than the repressive and depressive established sexual model. These observations are linked to Hardy's dual vision, the cosmic and the human, and to Henri Bergson's creative evolution. In conclusion, it is maintained, within Hardy's post-Darwinian evolving universe, all living creatures are caught up in 'neutral' processes of dissolution and transformation, changes that are inevitable and necessary to generation.

Cet article montre que le récit superficiel de The Return of the Native adhère aux théories et discours de la fin du XIX ${ }^{\mathrm{e}}$ siècle sur la dégénérescence et illustre une crise relative au genre. Cependant, lorsqu'on décode et met à nu les ambiguïtés textuelles, un sous-texte apparaît et permet une lecture autre dans laquelle tradition et convention sont subverties. Ainsi, le roman ouvre à une interprétation plus complexe de ce que signifie le fait d'être humain dans un univers en évolution. Le récit de The Return of the Native montre clairement que Hardy est pleinement conscient des discours controversés sur la dégénérescence de fin de siècle. Pourtant, il présente ces discours comme des idéologies profondément suspectes. L'étude de la structure du roman met au jour le croisement de deux trajectoires narratives opposées, l'une relative à la dégénérescence, l'autre à la régénération. Dans chaque intrigue, on observe une configuration soignée de personnages fondés sur un genre stéréotypé et des divisions éthiques binaires, aboutissant à la validation des valeurs régénératives et au châtiment de la transgression. En fait, une lecture précise révèle que Hardy s'en prend à la dégénérescence non pas de l'espèce humaine mais des institutions sociales et des conventions contre lesquelles ses protagonistes doivent lutter. Il défie les limites des divisions genrées et crée des personnages qui portent une vision nouvelle et puissamment dérangeante du masculin et du féminin dans un contexte plus large que celui du modèle sexuel établi. Ces remarques sont mises en relation avec la vision duale de Hardy - le cosmique et l'humain - et "l'évolution créative" de Bergson. Ainsi, dans l'univers évolutionniste et post-darwinien de Hardy, toutes les créatures vivantes sont prises dans des processus "neutres" de dissolution et de transformation, de changements qui sont inévitables et nécessaires à la génération. 
INDEX

Keywords: humanity, degeneration, Bergson (Henri), evolution, semiotic, symbolic, subtext Mots-clés: humanité, dégénérescence, Bergson (Henri), évolution, sémiotique, symbolique, sous-texte

\section{AUTHOR}

\section{MARIA ANTONIETTA STRUZZIERO}

Maria Antonietta Struzziero holds a Master in Translation Studies from La Sapienza University in Rome and a PhD in Linguistic and Literary Studies from the University of Salerno, Italy. She has published various articles on Thomas Hardy, Julian Barnes, Italo Calvino and Jeanette Winterson, and given papers at international conferences. She has co-edited "Voci ed echi: Quaderni di letteratura comparata”, Delta3 edizioni (2010), and translated two novels. Her main fields of research include: modernism; post-modernism; gender studies; auto/biographical writing; feminist theories; trauma studies. Her current research interests focus on the relationship between memory and identity in life writing narratives, as well as on a parallel study of the themes of loss and trauma in selected novels of Jeanette Winterson and Elena Ferrante. 